\title{
Critical Role of the mTOR Pathway in Development and Function of Myeloid-Derived Suppressor Cells in lal $^{-/-}$Mice
}

\author{
Xinchun Ding, ${ }^{* \dagger \dagger}$ Hong Du, ${ }^{* \dagger}$ Mervin C. Yoder, ${ }^{\S \oplus}$ and Cong Yan ${ }^{* \dagger \dagger}$ \\ From the Departments of Pathology and Laboratory Medicine, ${ }^{*}$ and Pediatrics, ${ }^{\top}$ the Indiana University Simon Cancer Center, ${ }^{\dagger}$ the Center for \\ Immunobiology, ${ }^{\ddagger}$ and the Herman B. Wells Center for Pediatric Research, ${ }^{\S}$ Indiana University School of Medicine, Indianapolis, Indiana
}

\author{
Accepted for publication \\ October 25, 2013. \\ Address correspondence to Cong \\ Yan, Ph.D., or Hong Du, Ph.D., \\ Department of Pathology and \\ Laboratory Medicine, Indiana \\ University School of Medicine, \\ 975 W Walnut St., IB424E, \\ Indianapolis, IN 46202. \\ E-mail: coyan@iupui.edu or \\ hongdu@iupui.edu.
}

\begin{abstract}
Lysosomal acid lipase (LAL) is essential for the hydrolysis of cholesteryl esters and triglycerides to generate cholesterol and free fatty acids in cellular lysosomes. Ablation of the lal gene $\left(\right.$ lal $\left.^{-/}\right)$systemically increased expansion of cluster of differentiation molecule 11b (CD11b), lymphocyte antigen 6G (Ly6G) myeloidderived suppressor cells (MDSCs) that caused myeloproliferative neoplasms in mice. Study of $l a l^{-/-}$bone marrow $\mathrm{Ly} 6 \mathrm{G}^{+}$MDSCs via transcriptional profiling showed increases in mammalian target of rapamycin (mTOR) signaling pathway transcripts. Injection of mTOR pharmacologic inhibitors into lal $^{-/-}$mice significantly reduced bone marrow myelopoiesis and systemic $\mathrm{CD} 11 \mathrm{~b}^{+} \mathrm{Ly}_{6 \mathrm{G}}{ }^{+}$cell expansion. Rapamycin treatment of $\mathrm{lal}^{-{ }^{-}-}$mice stimulated a shift from immature $\mathrm{CD} 11 \mathrm{~b}^{+} \mathrm{Ly}_{6 \mathrm{G}}{ }^{+}$cells to $\mathrm{CD} 11 \mathrm{~b}^{+}$single-positive cells in marrow and tissues and partially reversed the increased cell proliferation, decreased apoptosis, increased ATP synthesis, and increased cell cycling of bone marrow $\mathrm{CD}_{11} \mathrm{~b}^{+} \mathrm{Ly}_{6 \mathrm{G}}{ }^{+}$cells obtained from $\mathrm{lal}^{-{ }^{\prime-}}$ mice. Pharmacologic and siRNA suppression of mTOR, regulatory-associated protein of mTOR, rapamycininsensitive companion of mTOR, and Akt1 function corrected CD11 $\mathrm{b}^{+} \mathrm{Ly}_{6 \mathrm{G}}{ }^{+}$cell in lal $^{-/-}$mice development from $\mathrm{Lin}^{-}$progenitor cells and reversed the immune suppression on T-cell proliferation and function in association with decreased reactive oxygen species production, and recovery from impairment of mitochondrial membrane potential compared with control mutant cells. These results indicate a crucial role of LAL-regulated mTOR signaling in the production and function of $\mathrm{CD}_{11} \mathrm{~b}^{+} \mathrm{Ly}_{6 \mathrm{G}}{ }^{+}$cells. The mTOR pathway may serve as a novel target to modulate the emergence of MDSCs in those pathophysiologic states in which these cells play an immunosuppressive role. (Am J Pathol 2014, 184: 397-408; http://dx.doi.org/10.1016/ j.ajpath.2013.10.015)
\end{abstract}

Lysosomal acid lipase (LAL) is an essential enzyme that hydrolyzes cholesteryl esters and triglycerides in lysosomes. In humans, functional loss of the lal gene leads to two lipid storage diseases: Wolman disease and cholesteryl ester storage disease. ${ }^{1}$ In mice, ablation of the lal gene causes abnormal hematopoietic development, skewing progenitor cell differentiation toward an overabundance of myeloid cells that form myeloproliferative neoplasms. As a result, immature cluster of differentiation molecule 11b (CD11b), lymphocyte antigen 6G (Ly6G) cells expand dramatically and accumulate in the bone marrow, peripheral blood, immune organs (eg, spleen), and distal organs (eg, lung)., Unlike neutrophils and macrophages, these $\mathrm{CD}_{11} \mathrm{~b}^{+}$ $\mathrm{Ly}_{6 \mathrm{G}^{+}}$cells show strong T-cell immunosuppressive functions, $^{3}$ similar to myeloid-derived suppressor cells (MDSCs), in cancer. $^{4-6}$ Myeloid-specific expression of human LAL can rescue the abnormal hematopoietic development, expansion, and immunosuppressive functions of la ${ }^{-/-}$myeloid cells, and abrogate the associated pathogenic phenotypes displayed in multiple organs of $\mathrm{lal}^{-/-}$mice. ${ }^{3,7}$

To identify intrinsic defects in $l a l^{-/-}$myeloid lineage cells, transcriptional profiling of mutant and normal cells was performed using the GeneChip microarray analysis (Affymetrix, Santa Clara, CA). Ingenuity pathway analysis of the transcripts showed activation of mammalian target of rapamycin (mTOR) signaling in $\mathrm{lal}^{-/-}$bone marrow $\mathrm{Ly} \mathrm{G}^{+}$cells. $^{8}$ mTOR is the target of the immunosuppressant rapamycin and belongs to the phosphoinositide 3-kinase-related protein kinase family. ${ }^{9-11}$ mTOR functions as a nutrient, energy, and redox sensor.

Supported by NIH grants CA138759 and CA152099 (C.Y.), and HL087001 (H.D.). 
It controls cell growth, cell-cycle entry, and cell motility. ${ }^{12}$ Indeed, expression of genes that are involved in cell mitogenic signaling, cell cycle, histone variation, bioenergetics, and mitochondrial oxidative phosphorylation was altered substantially in microarray analysis of the $\mathrm{lal}^{-/-}$myeloid lineage cells compared with wild-type cells. mTOR is the catalytic subunit of two distinctive complexes: mTOR complex 1 (mTORC1) and mTOR complex 2 (mTORC2). Unique accessory proteins, regulatory-associated protein of mTOR (RAPTOR), and rapamycin-insensitive companion of mTOR (RICTOR) define the mTORC1 and mTORC2 complexes. In mammals, rapamycin inhibits mTORC1, but not mTORC2, whereas 2[4-amino-1-isopropyl-1H-pyrazolo(3,4-d)pyrimidine-3-yl]-1Hindo-5-ol (PP242) inhibits both complexes. ${ }^{13}$ The serine/ threonine protein kinase Akts serve as upstream regulators for mTORC 1 and downstream effectors for mTORC $2 .{ }^{12}$ Although it has been shown that mTOR plays a critical role in modulating cellular immune functions ${ }^{14}$ little is known of how mTOR contributes to MDSC production and function. Here, we report that pharmacologic inhibition of the mTOR activity by inhibitors or siRNA knockdown significantly rescues the intrinsic defects in the production and function of $l a l^{-/}$of $\mathrm{CD} 11 \mathrm{~b}^{+} \mathrm{Ly} 6 \mathrm{G}^{+}$cells, supporting the concept that LAL plays a central role in regulating the development, homeostasis, and function of $\mathrm{CD} 11 \mathrm{~b}^{+} \mathrm{Ly} 6 \mathrm{G}^{+}$MDSCs through mTOR signaling.

\section{Materials and Methods}

\section{Animal Care}

All scientific protocols involving the use of animals in this study were approved by the Institution Animal Care and Usage Committee of the Indiana University School of Medicine (Indianapolis, IN) and followed the guidelines established by the Panel on Euthanasia of the American Veterinary Medical Association. Protocols involving the use of recombinant DNA or biohazardous materials have been approved by the Institutional Biosafety Committee and followed the guidelines established by the National Institutes of Health. Animals were housed under Institution Animal Care and Usage Committeeapproved conditions in a secured animal facility at the Indiana University School of Medicine and were screened regularly for common pathogens. Experiments involving animal sacrifice used an approved euthanasia protocol.

\section{Rapamycin Treatment}

Rapamycin (LC Laboratories, Woburn, MA) initially was dissolved in $100 \%$ ethanol, stored at $-20^{\circ} \mathrm{C}$, and diluted further in an aqueous solution of 5.2\% Tween 20 (SigmaAldrich, St. Louis, MO) and 5.2\% polyethylene glycol 400 (2\% final ethanol concentration) immediately before use. Five-month-old $\mathrm{lal}^{-\prime-}$ mice were i.p. injected with $4 \mathrm{mg} / \mathrm{kg}$ rapamycin every day for 1 week, and the last injection was administered 2 to 4 hours before sacrificing the mouse. There were a total of eight injections.

\section{Western Blot Analysis}

Single cells from various mouse groups or siRNA-transfected cells were prepared as described previously. ${ }^{15}$ Protein extracts were prepared in radioimmunoprecipitation assay buffer and fractionated on a Novex 4-20\% Tris-Glycine Mini Gel (Invitrogen, Grand Island, NY). After transferring to the polyvinylidene difluoride membrane (Bio-Rad, Hercules, CA), the membrane was blotted with 5\% nonfat dry milk in PBS, anti-p-S6 (Ser235/236), S6, mTOR, Raptor, Rictor, RHEB, AKT1, AKT2, AKT3, or actin antibody (Cell Signaling Technology, Beverly, MA) was used to hybridize with the membrane. After incubation with the second antibody, proteins were detected with chemiluminescent substrate (Thermo Scientific, Rockford, IL).

\section{Fluorescence Activated Cell Sorting Analysis}

Single-cell suspensions from the bone marrow, spleen, blood, and lung were prepared as previously described. ${ }^{15}$ Approximately 1 to $3 \times 10^{6}$ cells from various organs were blocked with $\mathrm{Fc}$-receptor $(\mathrm{FcR})$ blocking antibodies (Abs) in fluorescence activated cell sorting buffer (BD Biosciences, San Jose, CA), followed by incubation with isotype control or surfacespecific primary Abs. For six-color hematopoietic progenitor cell analysis and sorting, ${ }^{16}$ a previously described procedure was followed. ${ }^{2}$ Lineage markers (biotin-CD3, -CD4, -CD8, -CD11b, -Gr-1, -Ter119, and -B220) and other marker antibodies (Sca-1, c-Kit, IL-7R $\alpha$, and CD34) were purchased from BD Biosciences. Anti-CD11b (M1/70) and anti-Ly6G (RB6$8 \mathrm{c5}$ ) were purchased from eBioscience (San Diego, CA). Cells were analyzed on a LSR II machine (BD Biosciences). Data were analyzed using BD Cell Quest Pro software (BD Biosciences). The total number of positive cells was calculated as the percentage of total gated viable cells. Quadrants were assigned using isotype control monoclonal Abs.

To measure phosphorylation of Stat proteins in CD11 $b^{+}$ Ly $6 \mathrm{G}^{+}$cells, bone marrow cells from 3- to 4-month-old wildtype or $l a l^{-/-}$mice were treated with $40 \mathrm{nmol} / \mathrm{L}$ rapamycin, or $40 \mathrm{nmol} / \mathrm{L}$ PP242 for 40 minutes in RPMI 1640 culture medium with $10 \%$ fetal bovine serum in a 96-well plate. The cells were labeled with anti-Ly6G and CD11b cell surface antibody (eBioscience), fixed, and permeabilized using BD Cytofix/ Cytoperm Fixation/Permeabilization Kit (BD Biosciences) according to the manufacturer's instructions. Cells were labeled with the Stat signaling molecule antibodies at $4^{\circ} \mathrm{C}$ overnight. Anti-pStat1(Tyr701) (Alexa Fluor 647 conjugate) antibody, anti-pSTAT3 (Tyr705) (Alexa Fluor 647 conjugate) antibody, anti-pSTAT5 (Tyr694) (Alexa Fluor 647 conjugate) antibody, anti-pSTAT2 (Tyr690) antibody, anti-pSTAT4 (Tyr693) antibody, and anti-rabbit IgG (Alexa Fluor 647 conjugate) were purchased from Cell Signaling Technology. Anti-pSTAT6 (Tyr641) antibody was purchased from Abcam (Cambridge, MA). The following day, the cells were washed and labeled with secondary antibody. Mean fluorescence intensities of Stat protein phosphorylation in the gated 


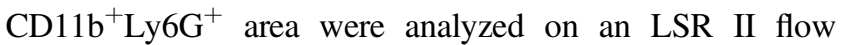
cytometer (BD Biosciences). Data were analyzed using FACStation software (BD Biosciences).

\section{Lin $^{-}$Bone Marrow Cell Isolation}

Bone marrow cells were isolated from mice (age, 8 to 10 weeks). Erythrocytes were lysed and $\mathrm{Lin}^{-}$bone marrow cells were isolated by removing blood lineage marker-positive cells with an immunomagnetic microbead technique. Bone marrow cells were labeled with a cocktail of biotin-coupled antibodies raised against lineage-specific antigens: CD11b, GR-1, B220, TER-119, and CD3e (Mouse Lineage Panel Kit; BD Pharmingen, San Diego, CA). After a 20-minute incubation with biotin-labeled primary antibodies at $4{ }^{\circ} \mathrm{C}$, unlabeled cells were separated on a depletion column using magnetic-activated cell sorting technology according to the manufacturer's instructions (Miltenyi Biotech, Auburn, CA). This method resulted in more than $95 \% \mathrm{Lin}^{-}$cells. Five days after in vitro culturing in RPMI1640 plus $10 \%$ fetal calf serum, CD11b ${ }^{+} \mathrm{Ly} 6 \mathrm{G}^{+}$cells that were derived from $\mathrm{Lin}^{-}$ cells were analyzed by flow cytometry.

\section{siRNA Knockdown of $\mathrm{Ly} 6 \mathrm{G}^{+}$Cells and $\mathrm{Lin}^{-}$Cells}

Ly6G ${ }^{+}$cells $\left(1 \times 10^{6}\right)$ and $\mathrm{Lin}^{-}$cells $\left(2 \times 10^{5}\right)$ were transfected with $25 \mathrm{nmol} / \mathrm{L}$ mTOR-specific or negative control siRNA (Dharmacon, Lafayette, CO) with Dharmacon siRNA transfection reagent according to the manufacturer's protocols. After 12 hours of transfection, cells were washed and co-cultured in wells with carboxyfluorescein diacetate succinimidyl diester (CFSE)-labeled wild-type $\mathrm{CD}^{+} \mathrm{T}$ cells $\left(\mathrm{Ly}^{+} \mathrm{G}^{+}\right.$cells versus $\mathrm{T}$ cell, 1:5) for 96 hours for T-cell proliferation and lymphokine release study.

\section{Cell-Cycle Analysis}

For cell-cycle measurement in bone marrow $\mathrm{CD} 11 \mathrm{~b}^{+} \mathrm{Ly}_{6 \mathrm{G}}{ }^{+}$ cells, cell suspensions from bone marrow of various treated mouse groups were labeled with anti-Ly6G and CD11b cell surface antibody (eBioscience). The cells were fixed and permeabilized using the BD Cytofix/Cytoperm Fixation/ Permeabilization Kit (BD Biosciences) according to the manufacturer's instructions, and then stained with $50 \mu \mathrm{g} / \mathrm{mL}$ propidium iodide at $4^{\circ} \mathrm{C}$ overnight. Cells were analyzed on an LSR II flow cytometer (BD Biosciences). Propidium iodide was gated and measured by ModFit LT software (Verity Software, Topsham, ME).

\section{ATP Measurement}

Single-cell preparation from the bone marrow was performed as described previously ${ }^{15}: 1 \times 10^{6}$ cells were rinsed with PBS and lysed with ATP-releasing buffer containing $100 \mathrm{mmol} / \mathrm{L}, \mathrm{pH} 7.8$, potassium phosphate buffer, $2 \mathrm{mmol} / \mathrm{L}$ EDTA, $1 \mathrm{mmol} / \mathrm{L}$ dithiothreitol, and $1 \%$ Triton $\mathrm{X}-100$
(Sigma-Aldrich). The ATP concentration of cell lysate was measured using the ATP determination kit (Invitrogen) according to the manufacturer's instructions. ATP levels were calculated as luminescence $/ 1 \times 10^{6}$ cells and normalized to the level of wild-type cells.

\section{BrdU Incorporation}

For cell proliferation analysis, wild-type and $l a l^{-/-}$littermates were inoculated i.p. with $1 \mathrm{mg}$ bromodeoxyuridine $(\mathrm{BrdU}) /$ mouse (BD Biosciences) 16 to 18 hours before sacrificing the mouse. Cells from the bone marrow were harvested and stained with surface markers CD11b nd Ly6G

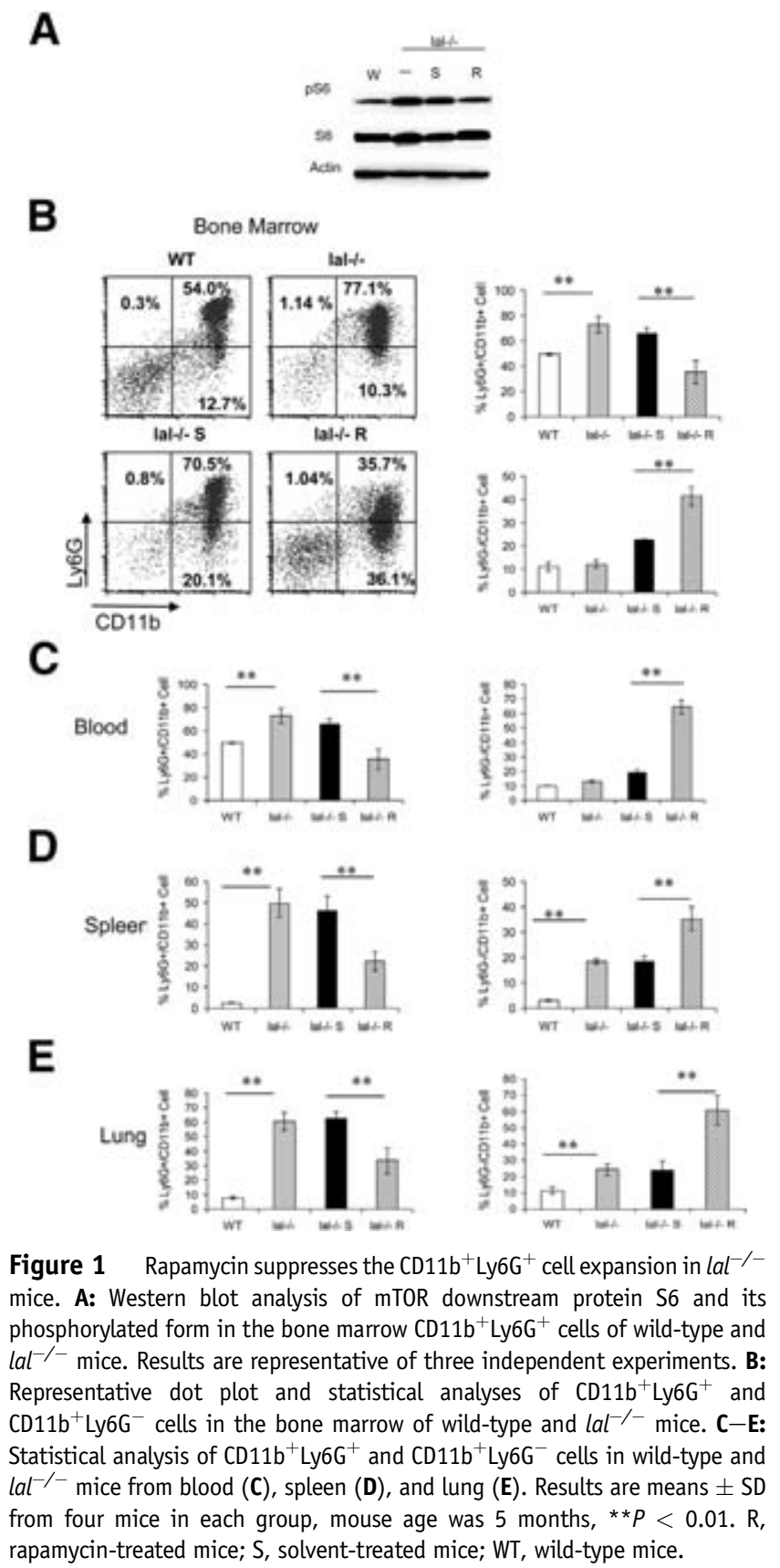


antibody. Labeled cells were washed twice with PBS and stained for BrdU using a BrdU flow kit (BD Pharmingen). Cells were fixed and permeabilized with BD Cytofix/ Cytoperm buffer (BD Biosciences), incubated with DNase I and washed again, followed by staining with fluorescent anti-BrdU antibody before analysis on the LSR II.

\section{Annexin V Binding}

The apoptotic cell population was determined by fluorescein isothiocyanate-labeled Annexin V staining (Apoptosis Detection Kit; BD Pharmingen, Bedford, MA). Cells from the bone marrow of wild-type and $\mathrm{lal}^{-1-}$ mice were stained with antibodies to surface markers CD11b and Ly6G, and washed twice with PBS. After resuspension of labeled cells in Annexin $\mathrm{V}$-binding buffer containing fluorescein isothiocyanate-conjugated Annexin V (1:20 dilution) and incubation at room temperature for 15 minutes, stained cells were analyzed by flow cytometry as soon as possible (within 1 hour). Nonspecific binding was blocked by pre-incubating the cells with $10 \mu \mathrm{g} / \mathrm{mL}$ rat IgG and anti-FcII/III.

\section{Mitochondrial Membrane Potential Measurement}

Cells were stained with the fluorescent dye JC-1 $(2 \mu \mathrm{mol} / \mathrm{L}$ final; Molecular Probes, Eugene, OR), anti-CD11b phycoerthrin cy7, anti-Ly6G allophycocyanin cy7, and analyzed for phycoerythrin (JC-1 red) and fluorescein isothiocyanate (JC-1 green) fluorescent cells in $\mathrm{CD}_{11} \mathrm{~b}^{+} \mathrm{Ly} 6 \mathrm{G}^{+}$cells by flow cytometry. Cells treated with $50 \mu \mathrm{mol} / \mathrm{L}$ carbonyl cyanide 3chlorophenylhydrazone for 5 minutes served as a fluorescein isothiocyanate-positive control.

\section{Isolation of $\mathrm{CD}^{+}{ }^{+} \mathrm{T}, \mathrm{Ly}_{6 \mathrm{G}}{ }^{+}$, and Lineage-Negative Cells}

To purify wild-type $\mathrm{CD} 4^{+} \mathrm{T}$ cells, erythrocyte-depleted splenocytes were incubated with anti-CD4-biotin antibody, followed by positive selection on magnetic beads and eluted from magnetic separation columns according to the manufacturer's instructions (Miltenyi Biotec). Because all $\mathrm{Ly} 6 \mathrm{G}^{+}$cells were $\mathrm{CD}_{11} \mathrm{~b}^{+}$positive in the bone marrow of $\mathrm{lal}^{-/-}$mice, ${ }^{3}$ and both $\mathrm{CD} 11 \mathrm{~b}$ and Ly6G protein markers were up-regulated in isolated bone marrow $\mathrm{Ly} 6 \mathrm{G}^{+}$cells by Affymetrix GeneChip microarray analysis, ${ }^{8}$ the Ly6G antibody was used for purification of $\mathrm{CD} 11 \mathrm{~b}^{+} \mathrm{Ly}_{6 \mathrm{G}}^{+}$cells. To purify $\mathrm{Ly} 6 \mathrm{G}^{+}$cells, erythrocyte-depleted cells from the bone marrow, spleen, or lung were incubated with anti-Ly6G-biotin antibody, followed by a similar magnetic selection. The purity of the $\mathrm{Ly} 6 \mathrm{G}^{+}$ cell population was typically higher than $90 \%$. For $\mathrm{Lin}^{-}$cell purification, erythrocyte-depleted cells from bone marrow were labeled with a mixture of biotin-coupled Abs raised against lineage-specific antibodies: CD11b, Gr-1, B220, TER-119, and $\mathrm{CD} 3 \varepsilon$ (mouse lineage panel kit; BD Biosciences) for $20 \mathrm{mi}-$ nutes at $4^{\circ} \mathrm{C}$. Unlabeled cells were separated on a depletion column using magnetic cell separation technology according to the manufacturer's instructions (Miltenyi Biotech). The purity
A

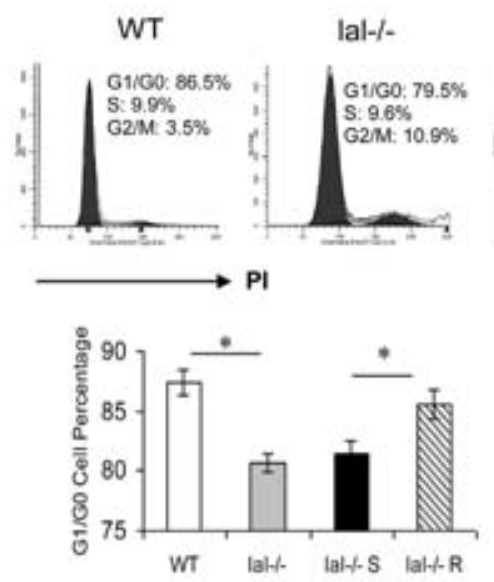

lal-- S
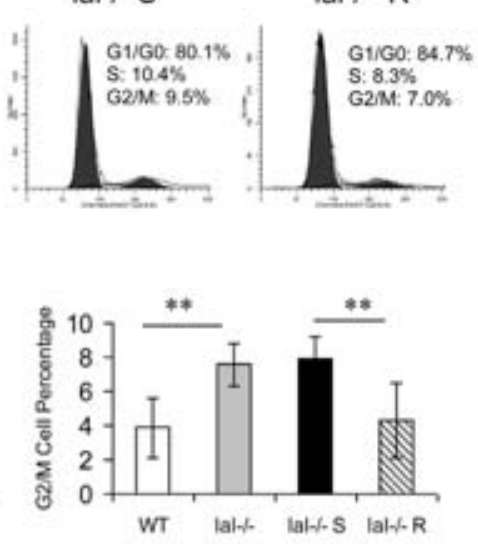

B

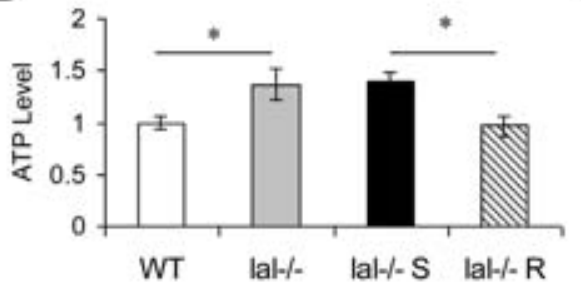

C

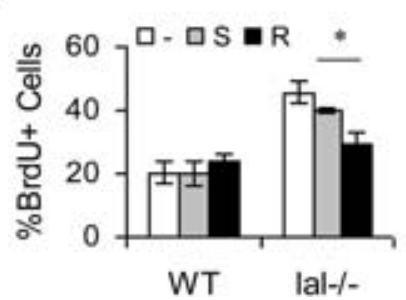

D

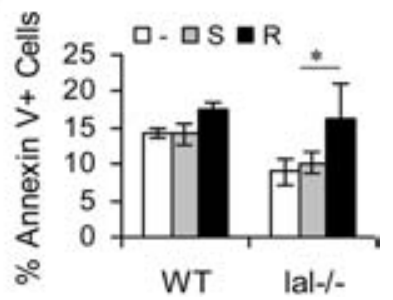

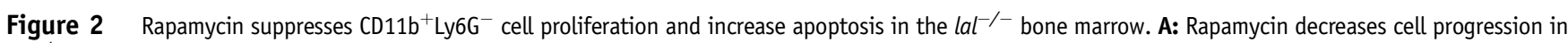
$\mathrm{lal}^{-/-}$bone marrow CD11b ${ }^{+} \mathrm{Ly}_{6 \mathrm{G}}{ }^{+}$cells. Representative and statistical cell-cycle analyses of bone marrow $\mathrm{CD}^{1} 1 \mathrm{~b}^{+} \mathrm{Ly}_{6 \mathrm{G}}{ }^{+}$cells by fluorescence activated cell sorting are

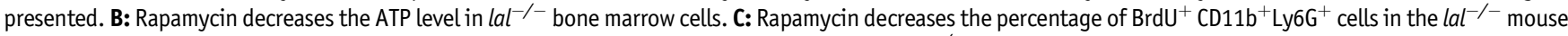

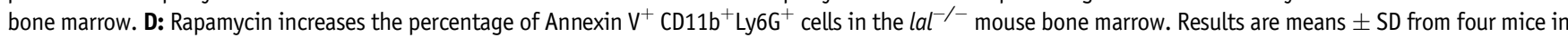
each group, mouse age was 5 months. ${ }^{*} P<0.05,{ }^{*} P<0.01$. PI, propidium iodide; $\mathrm{R}$, rapamycin-treated mice; $\mathrm{S}$, solvent-treated mice; WT, wild-type mice. 
of the $\mathrm{Lin}^{-}$cell population was typically higher than $95 \%$ using this method.

\section{T-Cell Proliferation and Lymphokine Release Assays in Vitro}

Isolated wild-type $\mathrm{CD} 4^{+}$cells were labeled in PBS containing 1 $\mu \mathrm{mol} / \mathrm{L} \mathrm{CFSE}$ (Molecular Probes) at $37^{\circ} \mathrm{C}$ for 10 minutes, and then pelleted and resuspended in complete medium for $40 \mathrm{mi}-$ nutes. $\mathrm{CD} 4^{+} \mathrm{T}$ cells were washed twice in PBS and then cultured in 96-well, flat-bottom plates coated with $2 \mu \mathrm{g} / \mathrm{mL}$ antiCD3 monoclonal Abs and $5 \mu \mathrm{g} / \mathrm{mL}$ anti-CD28 monoclonal Abs for 4 days in the presence or absence of $\mathrm{Ly} 6 \mathrm{G}^{+}$cells from various mouse groups at $37^{\circ} \mathrm{C}$. Freshly isolated $\mathrm{Ly}_{6 \mathrm{G}}^{+}$cells were pretreated with rapamycin or PP242, or pre-knocked down by siRNA overnight. The ratio between $\mathrm{Ly}_{6 \mathrm{G}}{ }^{+}$cells and $\mathrm{CD}^{+} \mathrm{T}$ cells was 1:5. Cells were harvested and stained with allophycocyanin-labeled anti-CD4 monoclonal Abs (eBiosciences). Proliferation of $\mathrm{CD}^{+}{ }^{+} \mathrm{T}$ cells was evaluated as $\mathrm{CFSE}$ dilution by fluorescence activated cell sorting. To measure Tcell secreting lymphokines, the OPEETA enzyme-linked immunosorbent assay kit for IL-2 was used according to the manufacturer's instructions (BD Biosciences).

\section{ROS Measurement}

Freshly isolated $\mathrm{Ly}_{6} \mathrm{G}^{+}$MDSCs from the bone marrow of $\mathrm{lal}^{-/-}$mice were recovered overnight, and treated with solvent, $4 \mathrm{nmol} / \mathrm{L}$ rapamycin, and $4 \mathrm{nmol} / \mathrm{L}$ PP2 42 for 45 minutes. Cells were washed and stained with $2 \mu \mathrm{mol} / \mathrm{L}$ $2^{\prime}, 7^{\prime}$-dichlorofluorescein diacetate (Invitrogen) at $37^{\circ} \mathrm{C}$ for 30 minutes, followed by washing and staining with antiCD11b and anti-Ly6G antibody on ice. The reactive oxygen species (ROS) level in $\mathrm{CD}_{11} \mathrm{~b}^{+} \mathrm{Ly}_{6} \mathrm{G}^{+}$cells was measured by flow cytometry. $\mathrm{Ly} 6 \mathrm{G}^{+}$cells from the bone marrow of wild-type mice were used as a control. In a ROS inhibition assay, the antioxidant $N$-Acetyl-L-cysteine was added to freshly isolated bone marrow $\mathrm{Lin}^{-}$cells every day for 5 days, followed by flow cytometry analysis of $\mathrm{CD} 11 b^{+} \mathrm{Ly}_{6 \mathrm{G}}{ }^{+}$cells emerging in culture.

\section{Statistical Analysis}

The results were means \pm SD of at least three independent experiments. A paired Student's $t$-test or analysis of variance was used to evaluate the significance of the differences. Statistical significance was set at a $P$ value of less than 0.05 .

\section{Results}

Rapamycin Treatment Decreases the CD11b $\mathrm{Ly}^{+} \mathrm{G}^{+}$Cell Population in $\mathrm{lal}^{-/-}$Mice

To assess if mTOR signaling was required for CD11 ${ }^{+} \mathrm{Ly} 6 \mathrm{G}^{+}$ cell expansion, 5-month-old $\mathrm{lal}^{-/-}$mice were treated i.p. with 4 $\mathrm{mg} / \mathrm{kg}$ mTOR inhibitor rapamycin every day for 1 week and the last injection was administered 4 hours before sacrificing the mice. Compared with wild-type mice, Western blot analysis of lysates from $\mathrm{lal}^{-1-}$ whole bone marrow cells showed constitutively increased phosphorylation of S6 (an mTOR downstream gene product), which was reduced on rapamycin treatment (Figure 1A). This observation confirmed our previous report that the mTOR pathway is activated in bone marrow cells of $\mathrm{lal}^{-1-}$ mice. ${ }^{8}$ Subsequently, cells from the bone
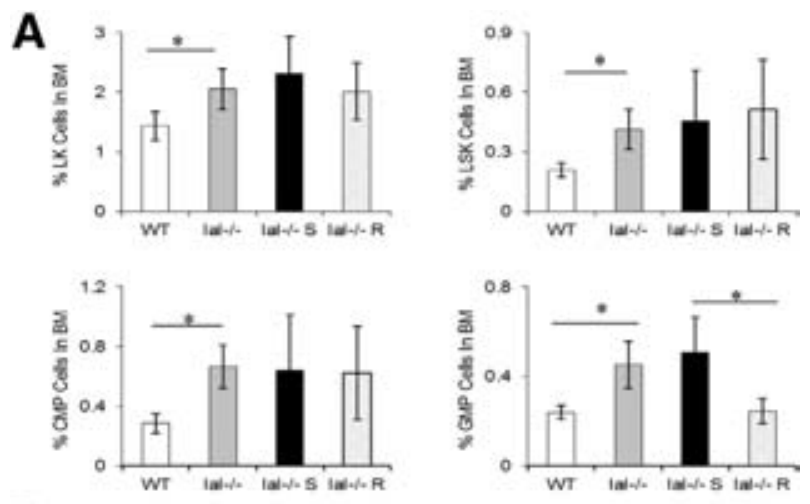

B
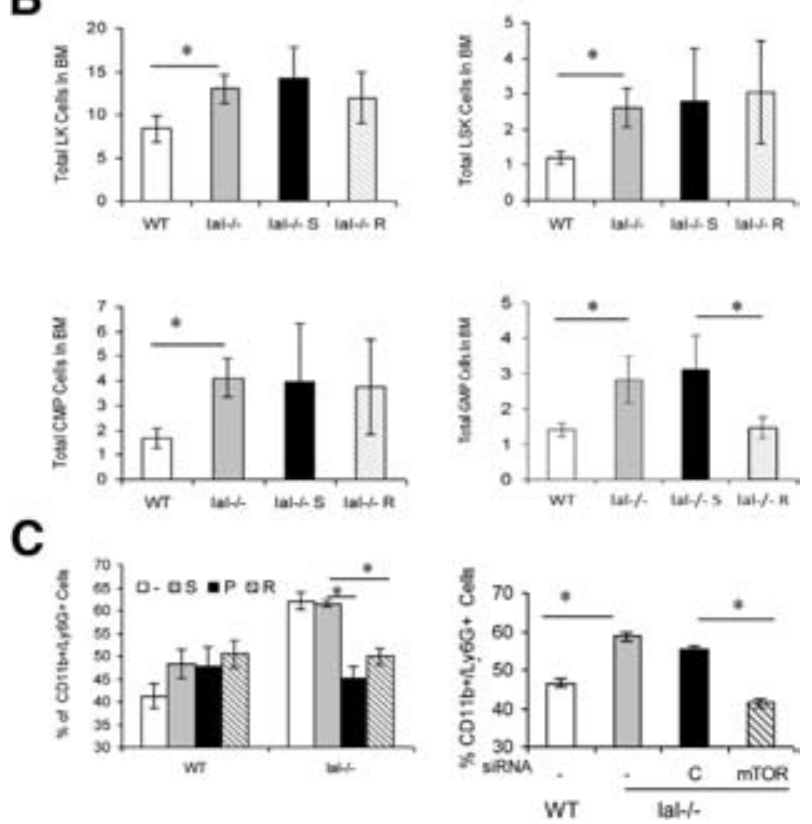

Figure 3 Rapamycin suppresses the abnormal development of progenitor cells in the $\mathrm{al}^{-/-}$bone marrow. A: Statistical analysis of the percentages of LK, LSK, common myeloid progenitor (CMP), and GMP populations in the bone marrow progenitor populations of wild-type or $\mathrm{lal}^{-1-}$ mice by fluorescence activated cell sorting. Results are means \pm SD from four mice in each group $(n=4)$, mouse age was 5 months. B: Statistical analysis of the total numbers $\left(\times 10^{5}\right)$ of LK, LSK, CMP, and GMP populations in the bone marrow progenitor populations of $\mathrm{lal}^{-I^{-}}$mice by fluorescence activated cell sorting. C: Statistical analysis of $\mathrm{CD}_{11} \mathrm{~b}^{+} \mathrm{Ly}_{\mathrm{G}} \mathrm{G}^{+}$cells from $\mathrm{Lin}^{-}$cells that were treated with rapamycin or PP242 by fluorescence activated cell sorting. Results are means \pm SD from four mice in each group, mouse age was 3

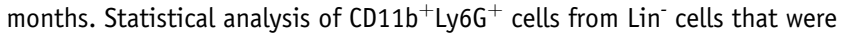
knocked down by control or mTOR siRNA. Results are means \pm SD from three mice in each group, mouse age was 3 months. ${ }^{*} P<0.05$. BM, bone marrow; C, control siRNA; LK, IL-7R ${ }_{\alpha}^{-}$Lin $^{-}$c-Kit ${ }^{+}$Sca-1 ${ }^{-}$; LSK, IL-7R R Lin $^{-}$c-Kit $^{+}$Sca$1^{+}$; mTOR, mTOR siRNA; P, PP242-treated mice; R, rapamycin-treated mice; $\mathrm{S}$, solvent-treated mice; WT, wild-type mice. 
A
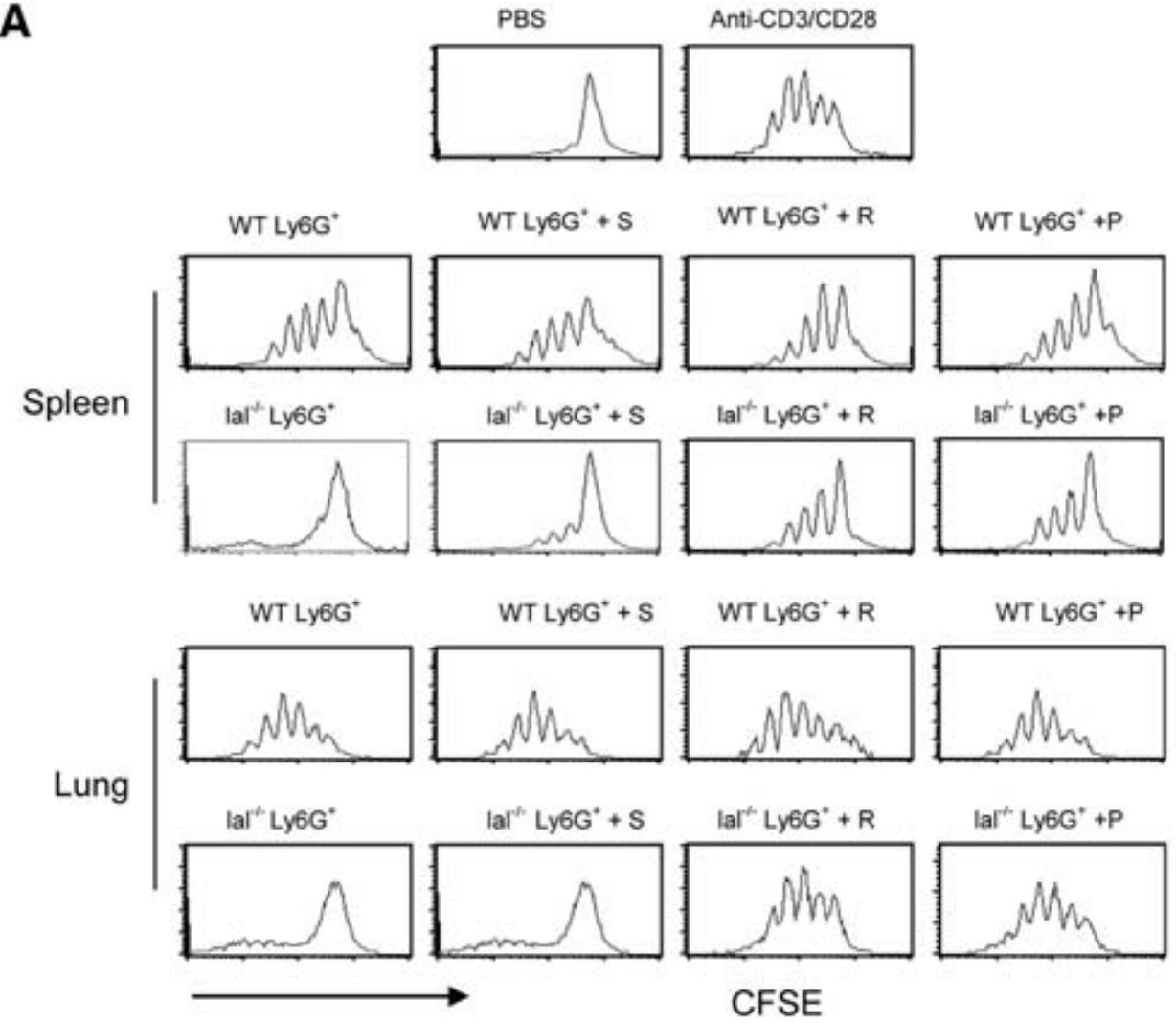

B
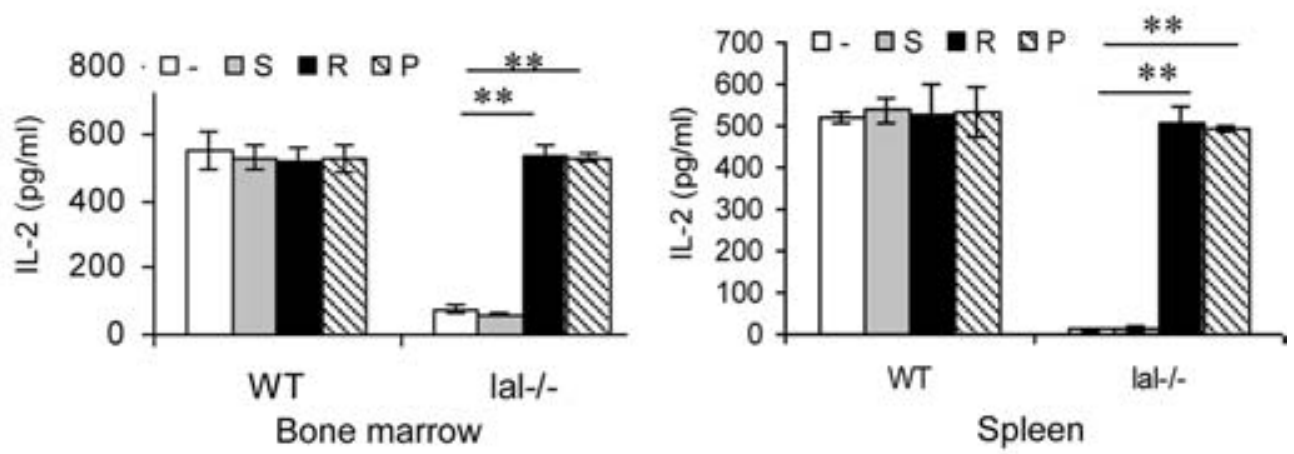

C

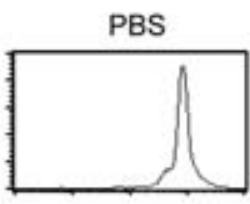

Anti-CD3/CD28
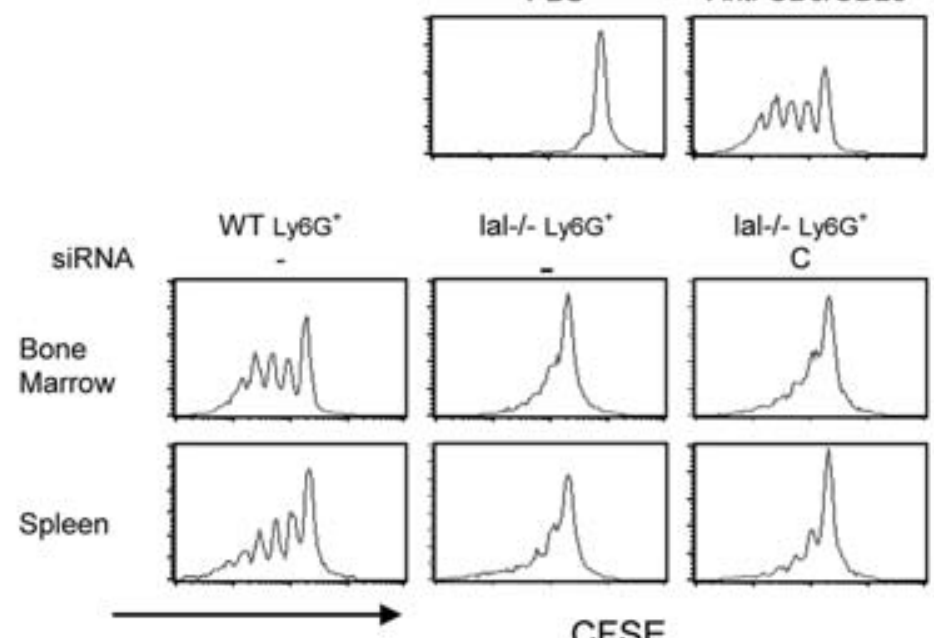

lal-/ - Ly6G ${ }^{*}$

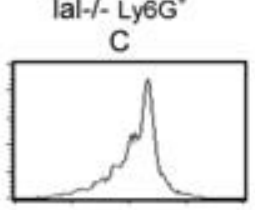

lal- $/-$ Ly $_{6 G^{*}}$ mTOR
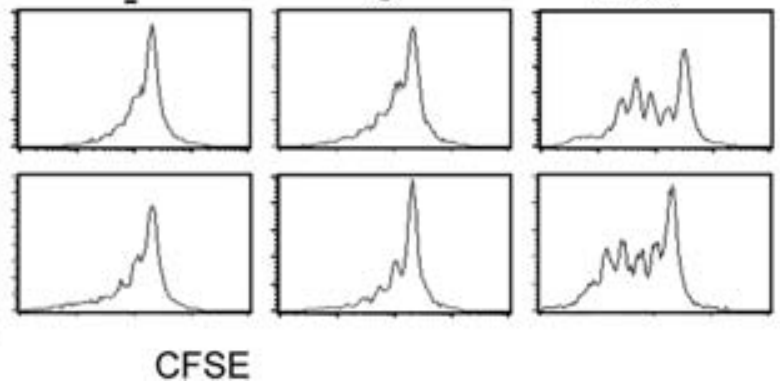
marrow, blood, spleen, and lungs of wild-type and $l a l^{-/-}$mice (treated with solvent or rapamycin) were isolated and stained with anti-CD11b and anti-Ly6G antibody for flow cytometry analysis. $\mathrm{CD} 11 \mathrm{~b}^{+} \mathrm{Ly}_{6 \mathrm{G}}{ }^{+}$cells from the $\mathrm{lal}^{--}$bone marrow compartment decreased dramatically after rapamycin treatment (35.7\%) compared with those in the solvent-treated control group (70.5\%) (Figure 1B). In contrast, CD11b single-positive cells from bone marrow of $\mathrm{lal}^{-1-}$ mice were increased in the rapamycin-treated group (36.1\%) compared with the solvent-treated group $(20.1 \%)$, suggesting that rapamycin facilitates differentiation from immature $\mathrm{CD} 11 \mathrm{~b}^{+} \mathrm{Ly} 6 \mathrm{G}^{+}$cells to $\mathrm{CD}_{11} \mathrm{~b}^{+}$cells. Similar results were found in the blood, lung, and spleen cells of $l a l^{-1-}$ mice (Figure 1, C-E). No significant change of $\mathrm{CD}_{11 \mathrm{~b}^{+}} \mathrm{Ly}_{6 \mathrm{G}}{ }^{+}$cells in the bone marrow was monitored in wild-type mice that were treated with solvent or rapamycin compared with untreated wild-type mice (Supplemental Figure S1). Therefore, only untreated wild-type mice were used as controls for the following studies.

\section{Rapamycin Treatment Decreases Proliferation and Increases Apoptosis of $\mathrm{CD}_{11 \mathrm{~b}^{+}} \mathrm{Ly}_{6 \mathrm{G}}{ }^{+}$Cells in $\mathrm{lal}^{-/-}$Mice}

As we reported previously, $l a l^{-/-}$bone marrow CD11b ${ }^{+} \mathrm{Ly}_{6 \mathrm{G}}{ }^{+}$ cells are highly proliferative in association with expression of many CDKs and cyclin genes. ${ }^{8}$ To test the functional role of mTOR signaling in this process, cell-cycle analysis was performed using bone marrow cells from wild-type and $\mathrm{lal}^{-1-}$ mice treated with solvent or rapamycin. In gated $\mathrm{CD} 11 \mathrm{~b}^{+} \mathrm{Ly}_{6 \mathrm{G}}{ }^{+}$ cells, proliferating cells in the G2/M stage were decreased $(9.5 \%$ versus $7.0 \%$ ), whereas the more quiescent cells in the G1/G0 stage $(80.1 \%$ versus $84.7 \%)$ were increased after rapamycin treatment in $\mathrm{lal}^{-1-}$ bone marrow cells compared with those of solvent-treated mouse marrow cells (Figure 2, A and B). As we reported previously, the ATP level was increased in bone marrow cells of $l a l^{-/-}$mice to meet the metabolic needs of the highly proliferative cells. ${ }^{8}$ Rapamycin injection into $l a l^{-1-}$ mice significantly reduced the ATP level in bone marrow cells, close to that of wild-type mice (Figure 2B). The increased cell proliferative activity of bone marrow $\mathrm{CD} 11 \mathrm{~b}^{+} \mathrm{Ly} 6 \mathrm{G}^{+}$cells of $\mathrm{lal}^{-/-}$mice was confirmed by BrdU incorporation analysis, in which rapamycin injection into $\mathrm{lal}^{-1-}$ mice reduced $\mathrm{BrdU}$ staining compared with that of solvent-injected $l a l^{-/-}$mice (Figure 2C). Therefore, rapamycin treatment decreased the proliferation of $l a l^{-/-} \mathrm{CD} 11 \mathrm{~b}^{+} \mathrm{Ly}_{6 \mathrm{G}} \mathrm{G}^{+}$cells. In addition, rapamycin injection into $\mathrm{lal}^{-1-}$ mice increased the apoptosis of $\mathrm{CD} 11 \mathrm{~b}^{+} \mathrm{Ly}_{6 \mathrm{G}}^{+}$cells compared with that of cells from solventinjected $l a l^{-/-}$mice using Annexin V staining (Figure 2D). When $\mathrm{CD} 11 \mathrm{~b}^{+} \mathrm{Ly} 6 \mathrm{G}^{-}$cells were analyzed, only BrdU incorporation was increased, whereas Annexin $\mathrm{V}$ staining remained relatively unchanged (Supplemental Figure S2).
Rapamycin Treatment Decreases the Abnormal Increase of Bone Marrow Myeloid Progenitor Cells Observed in $\mathrm{lal}^{-/-}$Mice

We previously showed that $\mathrm{CD} 11 \mathrm{~b}^{+} \mathrm{Ly}_{6 \mathrm{G}}{ }^{+}$cell expansion in $l a l^{-1-}$ mice is caused by an alteration of hematopoietic progenitor populations in the bone marrow, skewing cell differentiation toward an increase in the myeloid lineage. ${ }^{2}$ To assess how mTOR signaling is involved in bone marrow myeloid development in $l a l^{-/-}$mice, the percentages of the LK (IL-7R $\left.{ }_{\alpha}^{-} \mathrm{Lin}^{-} \mathrm{c}-\mathrm{Kit}^{+} \mathrm{Sca}-1^{-}\right)$, LSK (IL-7R $\mathrm{R}_{\alpha}^{-} \mathrm{Lin}^{-} \mathrm{c}-\mathrm{Kit}^{+}$ Sca- $1^{+}$), common myeloid progenitors (IL-7R $\mathrm{R}_{\alpha}^{-} \mathrm{Lin}^{-} \mathrm{c}-\mathrm{Kit}^{+}$ Sca- $1^{-}$CD $34^{+}$FcRII/III ${ }^{\text {low }}$ ), and granulocyte-macrophage progenitors (GMPs) (IL-7R $\mathrm{L} \mathrm{Lin}^{-} \mathrm{c}-\mathrm{Kit}^{+} \mathrm{Sca}^{-}{ }^{-} \mathrm{CD} 34^{+}$ FcRII/IIIp) were characterized after rapamycin injection into $\mathrm{lal}^{-/-}$mice. Rapamycin treatment resulted in a significant decrease in the GMP population compared with that of the solvent-treated $l a l^{-/-}$bone marrow (Figure 3, A and B and Supplemental Figure S3). No changes were observed in the LK, LSK, and common myeloid progenitor populations when comparing rapamycin- or solvent-treated marrow cells (Figure 3, A and B). Because CD11b ${ }^{+}$Ly $6 \mathrm{G}^{+}$cells are derived from GMP progenitor cells, this observation indicates that overactivation of the mTOR pathway contributes to abnormal differentiation of the increased GMP population in the $l a l^{-1-}$ bone marrow.

To confirm this in vivo observation, bone marrow lineage-negative $\left(\mathrm{Lin}^{-}\right)$cells from wild-type and $l a l^{-/-}$mice were isolated and cultured in vitro with solvent, rapamycin, and PP242. After 5 days of incubation, more CD11b ${ }^{+} \mathrm{Ly}_{6 \mathrm{G}^{+}}$ cells were derived from $\mathrm{Lin}^{-}$cells from the bone marrow of $l a l^{-1-}$ mice than those from the wild-type bone marrow (Figure 3C). Both mTOR inhibitor rapamycin and PP242 inhibited $\mathrm{CD} 11 \mathrm{~b}^{+} \mathrm{Ly}_{6 \mathrm{G}}{ }^{+}$cell differentiation from $\mathrm{lal}^{-/-} \mathrm{Lin}^{-}$ cells. Both inhibitors showed little effect on CD11 $\mathrm{b}^{+} \mathrm{Ly} 6 \mathrm{G}^{+}$ cell differentiation from wild-type $\mathrm{Lin}^{-}$cells (Figure 3C). Furthermore, siRNA knockdown of the mTOR molecule in lal $^{-/-} \mathrm{Lin}^{-}$cells decreased CD11b ${ }^{+} \mathrm{Ly} 6 \mathrm{G}^{+}$cell differentiation from $\mathrm{Lin}^{-}$cells compared with those of negative control siRNA knockdown (Figure 3C). Western blot showed that mTOR siRNA effectively suppressed mTOR protein expression (Supplemental Figure S4) and downstream S6 synthesis and phosphorylation (data not shown).

\section{Rapamycin Treatment Decreases the Immunosuppressive Function of $\mathrm{lal}^{-/-} \mathrm{Ly}_{6 \mathrm{G}}{ }^{+}$Cells}

T-cell proliferation and function are severely impaired in $\mathrm{lal}^{-/}$ mice. ${ }^{17}$ This is partially the result of to the strong immunosuppressive function of $\mathrm{CD} 11 \mathrm{~b}^{+} \mathrm{Ly} 6 \mathrm{G}^{+}$cells. $^{2}$ To assess if

\footnotetext{
Figure 4 Inhibition of the mTOR function suppresses $\mathrm{al}^{-/-} \mathrm{Ly} \mathrm{G}^{+}$cell immunosuppression on T-cell proliferation and lymphokine release. A: CFSE-labeled wildtype $\mathrm{CD}^{+}{ }^{+} \mathrm{T}$ cells were stimulated with anti-CD3 and anti-CD28 antibodies, and co-cultured with $\mathrm{Ly}_{6 \mathrm{G}}{ }^{+}$cells from the spleen or lung of wild-type or lal ${ }^{-1-}$ mice, pretreated with solvent $(S)$, rapamycin (R), or PP242 (P). B: Statistical analyses of IL-2 release from wild-type CD4 ${ }^{+}$T cells stimulated with CD3 and CD28 antibodies, and co-cultured with $\mathrm{Ly}_{6 \mathrm{G}} \mathrm{G}^{+}$cells from bone marrow or spleen of wild-type or lal ${ }^{-/-}$mice, pretreated with solvent (S), rapamycin (R), or PP242 (P). Results are means \pm $\mathrm{SD}$ from three mice in each group, mouse age was 5 months. ${ }^{* *} P<0.01$. C: CFSE-labeled CD4 ${ }^{+} T$ cells were stimulated with anti-CD3 and anti-CD28 antibodies, and cocultured with $\mathrm{Ly}_{6 \mathrm{G}}{ }^{+}$cells from bone marrow or spleen of wild-type or lat ${ }^{-/}$mice, pre-knocked down with control (C) siRNA or mTOR (mTOR) siRNA.
} 
mTOR signaling plays a role in MDSC suppression on $\mathrm{T}$-cell proliferation and function, $\mathrm{CD} 4^{+} \mathrm{T}$ cells were isolated from wild-type mouse spleen, labeled with CFSE, and co-cultured with $\mathrm{Ly} 6 \mathrm{G}^{+}$cells (based on our previous
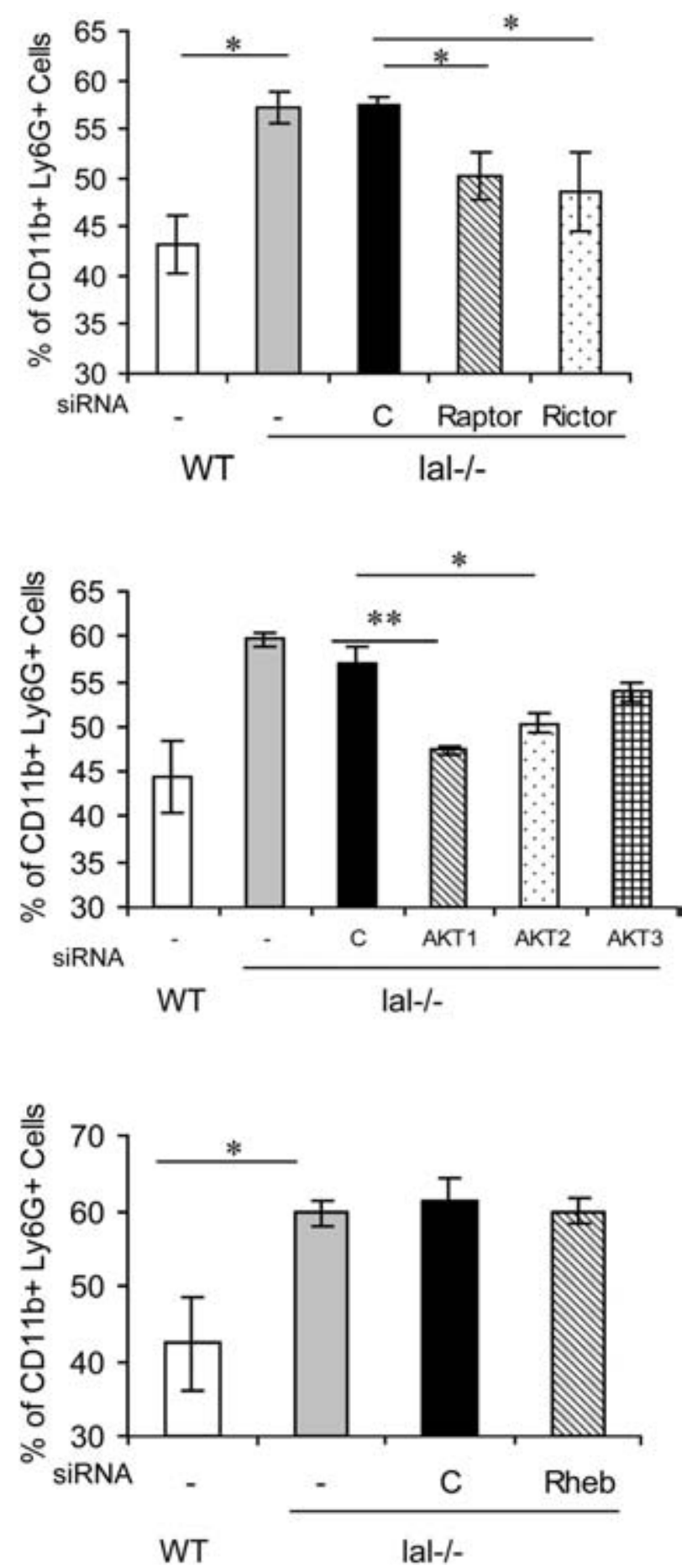

Figure 5 Inhibition of Raptor, Rictor, and Akt suppresses $\mathrm{lal}^{-1-}$ $\mathrm{CD} 11 \mathrm{~b}^{+} \mathrm{Ly}_{6 \mathrm{G}}{ }^{+}$cell differentiation from $\mathrm{Lin}^{-}$cells. Statistical analysis of

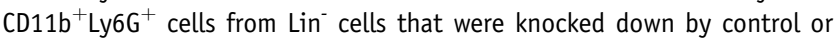
siRNA. Results are means \pm SD from three mice in each group, mouse age was 5 months. ${ }^{\star} P<0.05,{ }^{*} P<0.01$. C, control siRNA; WT, wild-type mice. reports, almost all $\mathrm{Ly}_{6} \mathrm{G}^{+}$cells are $\mathrm{CD} 11 \mathrm{~b}^{+}$in the bone marrow of $l a l^{-/-}$mice) from $\mathrm{lal}^{-/-}$mouse spleen or lungs (pretreated with or without rapamycin or PP242 overnight). $\mathrm{CD} 4{ }^{+} \mathrm{T}$-cell proliferation was decreased significantly when co-cultured with $\mathrm{lal}^{-/-} \mathrm{Ly}_{6 \mathrm{G}}^{+}$cells compared with those co-cultured with wild-type $\mathrm{Ly}_{6 \mathrm{G}}^{+}$cells. Pretreatment with rapamycin or PP242 reversed the immunosuppressive function of $\mathrm{lal}^{-1-} \mathrm{Ly} \mathrm{G}^{+}$cells on $\mathrm{CD}^{+} \mathrm{T}$ cells (Figure 4A and Supplemental Figure S5A). In addition, blocking mTOR function using pharmacologic inhibitors in $\mathrm{lal}^{-/-} \mathrm{Ly} 6 \mathrm{G}^{+}$cells from the bone marrow and spleen suppressed $\mathrm{CD} 4^{+} \mathrm{T}$-cell lymphokine IL-2 release (Figure 4B). Knockdown of mTOR by siRNA in $l a l^{-/-} \mathrm{Ly}_{6 \mathrm{G}}{ }^{+}$cells also reversed the immunosuppressive function of $l a l^{-/-} \mathrm{Ly}_{6 \mathrm{G}}{ }^{+}$cells on T-cell proliferation (Figure 4C and Supplemental Figure S5B).

\section{Knocking Down Raptor, Rictor, and Akt Decreases MDSC Production in $\mathrm{lal}^{-/-}$Mice}

To assess which of the mTOR complexes (mTORC1 or mTORC2) is involved in $\mathrm{CD} 11 \mathrm{~b}^{+} \mathrm{Ly} 6 \mathrm{G}^{+}$cell differentiation, $\mathrm{Lin}^{-}$cells from wild-type and $l a l^{-/-}$mice were isolated and cultured in vitro and transfected with siRNAs of control, Raptor, Rictor, Akt1, Akt2, Akt3, and Rheb molecules. As assessed by protein expression, siRNAs were able to suppress protein expression levels of the corresponding molecules effectively (Supplemental Figure S4). After 5 days of incubation, Raptor, Rictor, Akt1, and Akt2 knockdown inhibited CD $11 b^{+} \mathrm{Ly}_{6 \mathrm{G}}^{+}$cell differentiation from $\mathrm{lal}^{-/-} \mathrm{Lin}^{-}$cells. Akt3 (no detectable Akt3 protein in MDSCs, Supplemental Figure S4) and Rheb knockdown showed little effects (Figure 5). Therefore, both mTORC1 and mTORC2 are involved in abnormal differentiation of $\mathrm{CD} 11 \mathrm{~b}^{+} \mathrm{Ly} 6 \mathrm{G}^{+}$cells from $\mathrm{Lin}^{-}$cells of $\mathrm{lal}^{-/-}$mice.

\section{Knocking Down Raptor, Rictor, or Akt Decreases} Immunosuppressive Function of $\mathrm{Ly} 6 \mathrm{G}^{+}$cells in $\mathrm{lal}^{-/-}$ Mice

To assess which of the mTOR complexes (mTORC1 or mTORC2) is involved in lal ${ }^{-/-}$MDSC suppression on T-cell proliferation and function, $\mathrm{CD} 4^{+} \mathrm{T}$ cells were isolated from wild-type mouse spleen, labeled with CFSE, and co-cultured with $\mathrm{Ly} 6 \mathrm{G}^{+}$cells from the $\mathrm{lal}^{-/-}$bone marrow or spleen that were treated with control, Raptor, or Rictor siRNA. Raptor and Rictor knockdown in $\mathrm{lal}^{-1-} \mathrm{Ly} 6 \mathrm{G}^{+}$cells reversed their inhibitory effects on $\mathrm{CD} 4^{+} \mathrm{T}$-cell proliferation compared with those of control siRNA treatment in $\mathrm{lal}^{-1-} \mathrm{Ly} \mathrm{G}^{+}$cells (Figure 6A, Supplemental Figure S6). Akt1 and Akt2 knockdown by siRNA in $\mathrm{lal}^{-/-} \mathrm{Ly}_{6 \mathrm{G}}{ }^{+}$cells also reversed their immunosuppressive function on T-cell proliferation (Figure 6A). In addition, blocking functions of mTOR, Raptor, Rictor, and Akt1 by siRNA in $\mathrm{lal}^{-1-} \mathrm{Ly}_{6 \mathrm{G}}{ }^{+}$cells reversed their inhibition on $\mathrm{CD} 4{ }^{+}$ T-cell lymphokine release, whereas Akt 2 and Akt3 knockdown showed no significant effect (Figure 6B). 
Rapamycin Treatment Decreases Abnormal

Mitochondrial Membrane Potential and ROS Production in MDSCs of the $\mathrm{lal}^{-1-}$ Bone Marrow

ROS is an important mediator for MDSCs to suppress T-cell proliferation and function. ${ }^{6}$ An increase in cellular ROS often is associated with mitochondrial damage. In $\mathrm{lal}^{-1-}$ mice, both damaged mitochondrial function and ROS overproduction were observed. ${ }^{8}$ To see if rapamycin treatment corrects these malfunctions as a mechanism to abrogate immune suppression displayed by $l a l^{-1-} \mathrm{Ly} 6 \mathrm{G}^{+}$cells, $\mathrm{Ly}_{6 \mathrm{G}}{ }^{+}$cells were isolated from the bone marrow of $\mathrm{lal}^{-1-}$ mice and rapamycin treatment partially recovered mitochondrial membrane potential in Ly6G ${ }^{+}$cells (Figure 7A). Both rapamycin and PP242 treatments suppressed ROS production in $\mathrm{lal}^{-1-}$ bone marrow ${\text { Ly } 6 \mathrm{G}^{+}}^{+}$cells (Figure 7B). Antioxidant $N$-acetyl-L-cysteine treatment protected against ROS-suppressed abnormal differentiation of $\mathrm{Lin}^{-}$progenitor cells to $\mathrm{CD} 11 \mathrm{~b}^{+} \mathrm{Ly}_{6 \mathrm{G}}^{+}$cells

A

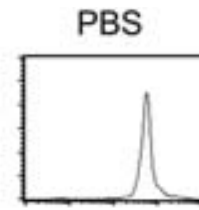

Anti-CD3/CD28
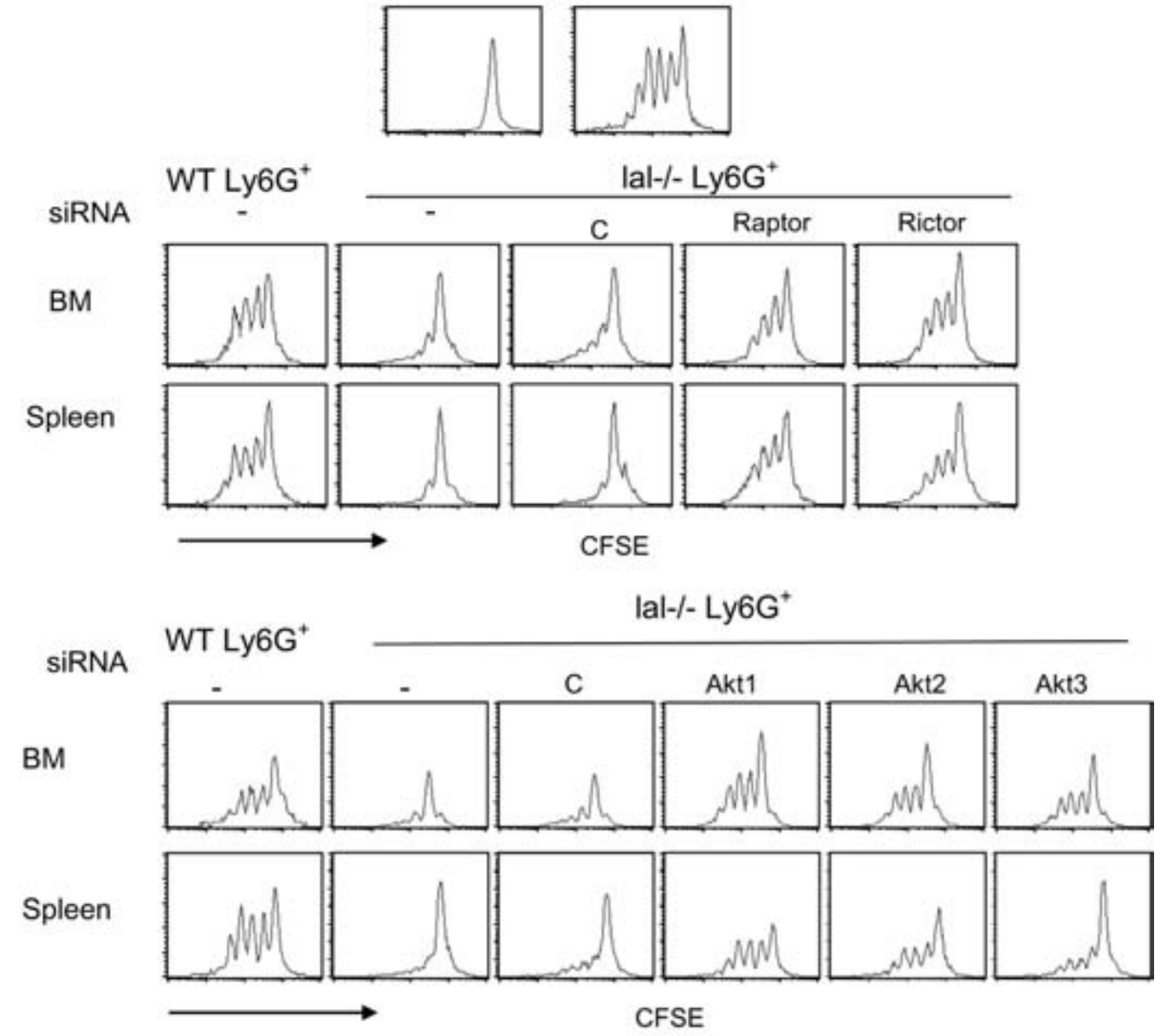

B
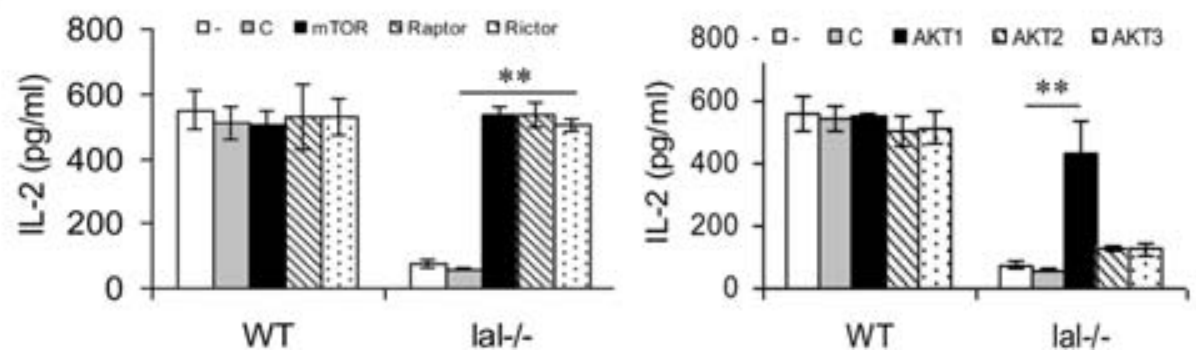

Figure 6 Inhibition of Raptor, Rictor, and Akt suppresses immunosuppression of lal ${ }^{-1-}$ Ly6G $^{+}$cells on T-cell proliferation and lymphokine release. A: CFSElabeled $\mathrm{CD}_{4}^{+} \mathrm{T}$ cells were stimulated with anti-CD3 and anti-CD28 antibodies, and co-cultured with $\mathrm{Ly}_{6 \mathrm{G}}{ }^{+}$cells from bone marrow or spleen of wild-type or $\mathrm{lal}^{-/-}$mice, which were pre-knocked down with control (C) siRNA or Raptor, Rictor, Akt1, Akt2, Akt3, and Rheb siRNA. B: Statistical analyses of IL-2 release from wild-type $\mathrm{CD}^{+}{ }^{+}$T cells that were stimulated with anti-CD3 and anti-CD28 antibodies, and co-cultured with Ly6G ${ }^{+}$cells from the bone marrow of wild-type or $l a l^{-1-}$ mice, which were pre-knocked down with control (C) siRNA or mTOR, Raptor, Rictor, Akt1, Akt2, and Akt3 siRNA. Results are means \pm SD from three to four mice in each group, mouse age was 5 months. ${ }^{* *} P<0.01$. BM, bone marrow. 
(Figure 7C). Therefore, rapamycin suppresses the $l a l^{-1-}$ MDSC development at least partially through correcting mitochondrial function and inhibiting ROS overproduction. Interestingly, the increased phosphorylation levels (activation)

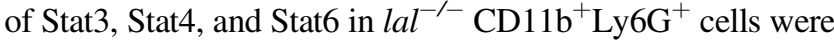
inhibited by mTOR inhibitor treatment (Figure 7D).

\section{Discussion}

MDSCs are immature myeloid cells that facilitate pathogenic processes in many chronic diseases. ${ }^{18}$ Understanding the molecular mechanisms that control MDSC development and function is essential to control the formation and progression of these inflammation-induced diseases. As we reported previously, LAL plays a critical role in MDSC development and immunosuppressive functions, which contribute to multiple chronic diseases in multiple organs in lal $^{-/-}$mice. $^{2,3}$ Affymetrix GeneChip microarray analysis showed that LAL deficiency leads to activation of the mTOR pathway in the $l a l^{-1-}$ bone marrow $\mathrm{Ly} 6 \mathrm{G}^{+}$MDSCs. It is well known that translocation to the lysosomal surface is essential for mTOR activation. ${ }^{19}$
To study if the mTOR pathway is required for CD11b $\mathrm{L}^{+} \mathrm{Ly} \mathrm{G}^{+}$ cell expansion in $l a l^{-/-}$mice, a pharmacologic inhibition of mTOR function was used. Injection of rapamycin into $l a l^{-/-}$ mice effectively blocked mTOR overactivation in $l^{-/-}$bone marrow cells, as indicated by reduced phosphorylation of the mTOR downstream S6 protein (Figure 1A). Rapamycin treatment also significantly reduced $\mathrm{CD} 11 \mathrm{~b}^{+} \mathrm{Ly}_{6 \mathrm{G}}{ }^{+}$cell expansion in the bone marrow, blood, spleen, and lung of $\mathrm{lal}^{-/-}$mice. Concurrently, the $\mathrm{CD}_{1} 1 \mathrm{~b}^{+}$cell population was increased in these organs of $l a l^{-/-}$mice (Figure 1).

We previously reported that $l a l^{-1-} \mathrm{CD} 11 \mathrm{~b}^{+} \mathrm{Ly}_{6 \mathrm{G}}^{+}$cells showed severe intrinsic cellular defects, including increased cell-cycle progression, cell proliferation, ATP production, and decreased apoptotic activity and mitochondrial membrane potential. ${ }^{20}$ Mitochondrial dysfunction often is linked to ROS overproduction, which plays an important role in the immune suppression of $\mathrm{T}$ cells. ${ }^{4,5}$ Because the mTOR signaling pathway has a profound impact on multiple cellular activities, such as cell-cycle progression, cell metabolism and energy generation, mitochondrial function, and ROS production, we have focused on evaluating the role of mTOR function in the production and function of MDSCs. Our studies showed that rapamycin and PP242 treatment of $l a l^{-/-}$

A
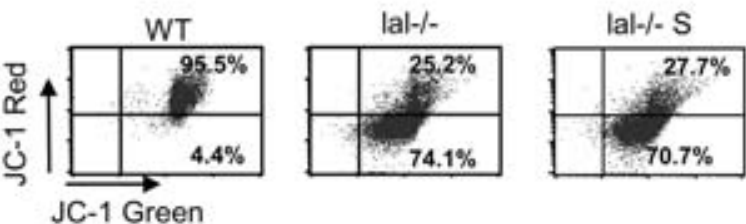

lal-/- R
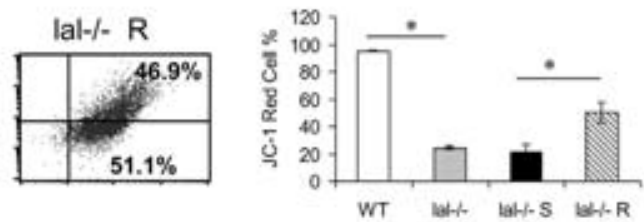

B
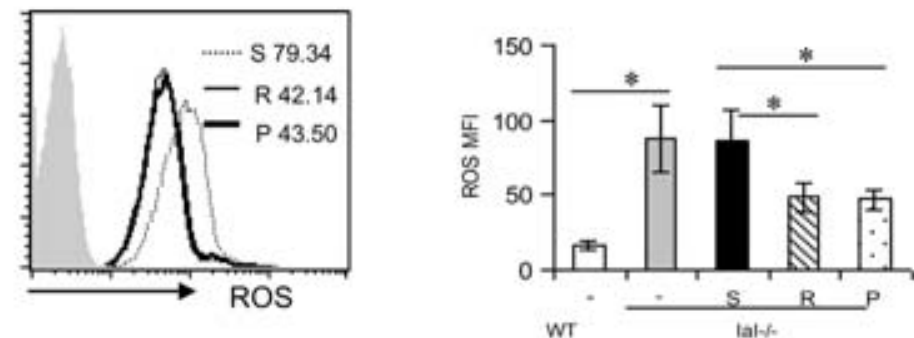

C

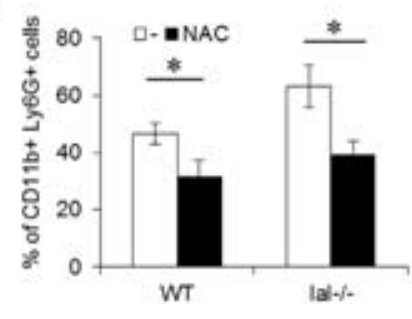

D
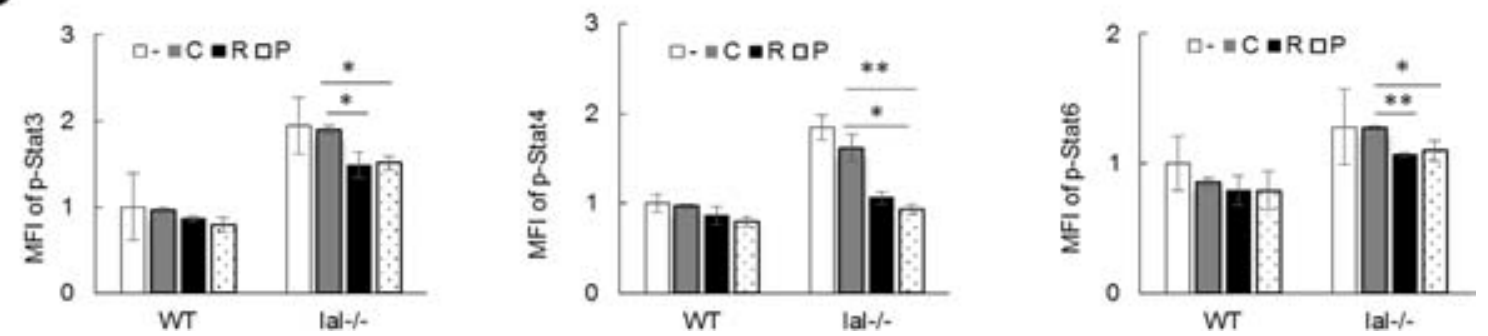

Figure 7 Rapamycin reverses damaged mitochondrial membrane potential, and suppresses ROS production and Stat phosphorylation in Ly6 $\mathrm{G}^{+}$cells of the $\mathrm{lal}^{-1-}$ bone marrow. A: Rapamycin increased mitochondrial membrane potential in $\mathrm{lal}^{-/-}$bone marrow $\mathrm{Ly}^{-\mathrm{G}^{+}}$cells. A representative dot plot analysis of the JC-1 red and JC-1 green profile by fluorescence activated cell sorting is shown. JC-1 red shows healthy mitochondrial membrane potential, whereas JC-1 green shows impaired mitochondrial membrane potential. B: Rapamycin decreased the ROS production in lal ${ }^{-/-}$bone marrow Ly $6 \mathrm{G}^{+}$cells. Both a representative (shaded area, isotype control) and statistical analyses of mean fluorescent intensity (MFI) by flow cytometry are shown. C: Antioxidant N-Acetyl-L-cysteine

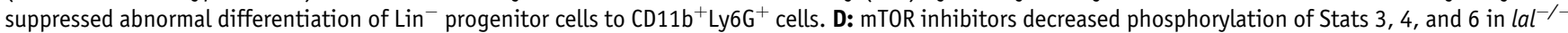
bone marrow $\mathrm{Ly}_{6 \mathrm{G}}{ }^{+}$cells. Results are means $\pm \mathrm{SD}$ from three mice in each group, mouse age was 5 months. ${ }^{*} P<0.05,{ }^{*} P<0.01$. NAC, $N$-acetyl-L-cysteine; P, PP242-treated mice; R, rapamycin-treated mice; S, solvent-treated mice; WT, wild-type mice. 
mice significantly corrected abnormal cell-cycle activity, ATP production, mitochondrial membrane potential, and ROS production in $\mathrm{lal}^{-1-}$ bone marrow CD $11 \mathrm{~b}^{+} \mathrm{Ly} 6 \mathrm{G}^{+}$cells (Figures 2 and 7).

The abnormal development of hematopoietic progenitor cells in the bone marrow largely contributes to the $\mathrm{CD} 11 \mathrm{~b}^{+} \mathrm{Ly}_{6 \mathrm{G}}{ }^{+}$ cell systemic expansion in $l a l^{-/}$mice. ${ }^{2}$ Rapamycin treatment significantly decreased the total size and frequency of the GMP population, but not LK, LSK, and common myeloid progenitor populations in the $\mathrm{lal}^{-1-}$ bone marrow in vivo (Figure 3, A and B). When Lin ${ }^{-}$cells were tested in vitro, inhibition of mTOR signaling by both pharmacologic inhibitors (rapamycin and PP242) and siRNA approaches reduced Lin $^{-}$cells to differentiate into $\mathrm{CD} 11 \mathrm{~b}^{+} \mathrm{Ly}_{6 \mathrm{G}}{ }^{+}$cells (Figure $3 \mathrm{C}$ ). Therefore, activation of the mTOR signaling pathway is critically involved in mediating myelopoiesis during hematopoietic development in the $\mathrm{lal}^{-1-}$ bone marrow by controlling abnormal differentiation of progenitor cells to $\mathrm{CD} 11 \mathrm{~b}^{+} \mathrm{Ly} 6 \mathrm{G}^{+}$cells. It seems that both mTORC1 and mTORC2 participate in this pathogenic process in $l a l^{-1-}$ mice because knockdown of Raptor and Rictor also reduced the ability of $\mathrm{lal}^{-1-} \mathrm{Lin}^{-}$cells to differentiate into

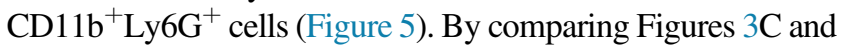
5 , it seems that the combinatorial effects of Raptor and Rictor were equal to that observed in the mTOR study, suggesting an additive contribution of Raptor and Rictor in mediating mTOR signaling. This supports the concept that both mTORC1 and mTORC 2 are activated in $\mathrm{lal}^{-/-}$myeloid cells and contribute to $\mathrm{CD}_{11} \mathrm{~b}^{+} \mathrm{Ly}_{6 \mathrm{G}}{ }^{+}$cell development during LAL deficiency. Akts can be both upstream and downstream of mTORC1 or mTORC2. Knockdown of Akt1 and Akt2 reduced differentiation of $\mathrm{lal}^{-1-} \mathrm{Lin}^{-}$cells into CD11b ${ }^{+} \mathrm{Ly}_{6 \mathrm{G}}^{+}$cells (Figure 5). Again, an additive contribution of Akt1 and Akt2 was observed in mediating mTOR signaling. It has been proposed that translocation of mTORC1 to the lysosomal surface results in its activation by interacting with Rheb. ${ }^{19}$ To test if this is the case in lal $^{-1-}$ bone marrow $\mathrm{CD} 11 \mathrm{~b}^{+} \mathrm{Ly}_{6 \mathrm{G}}{ }^{+}$cells, the Rheb activity was knocked down by siRNA in $\mathrm{Lin}^{-}$cells. It seems that Rheb knockdown had no effect on the correction of $l a l^{-1-} \mathrm{Lin}^{-}$cells to differentiate into $\mathrm{CD} 11 \mathrm{~b}^{+} \mathrm{Ly}_{6 \mathrm{G}}^{+}$cells (Figure 5). Because the lysosomal membrane acts as a platform for mTOR signaling, the lack of LAL activity may change lipid composition on the lysosomal membrane, therefore influencing the endomembrane trafficking, and stimulate mTOR activity through a Rheb-independent mechanism to stimulate $l a l^{-/}$ $\mathrm{Lin}^{-}$cells to differentiate into CD11b ${ }^{+} \mathrm{Ly} 6 \mathrm{G}^{+}$cells.

The characteristic functional feature of MDSCs is their strong ability to suppress T-cell proliferation and function (lymphokine release). We previously reported that $\mathrm{Ly}_{6 \mathrm{G}}{ }^{+}$ cells from $\mathrm{lal}^{-1-}$ mice show a much stronger immunesuppressive function on $\mathrm{T}$ cells than those from wild-type mice. ${ }^{2}$ When mTOR was inhibited in $l a l^{-/-} \mathrm{Ly} 6 \mathrm{G}^{+}$cells by the pharmacologic inhibitors rapamycin or PP242, or use of siRNA to diminish mTOR pathway functions, $\mathrm{Ly} 6 \mathrm{G}^{+}$cells from the spleen, lung, and bone marrow of $l a l^{-/-}$mice all showed a reduced ability to suppress $\mathrm{CD} 4^{+} \mathrm{T}$-cell proliferation (Figure 4A), and inhibit IL-2 lymphokine release
(Figure 4B). Because both Raptor and Rictor siRNA knockdown reduced immune suppression of $l a l^{-/} \mathrm{Ly}_{6} \mathrm{G}^{+}$cells on $\mathrm{CD}^{+}$T-cell proliferation and IL-2 lymphokine release (Figure 6, A and B), both mTORC1 and mTORC2 pathways contribute to $\mathrm{lal}^{-/-} \mathrm{Ly} \mathrm{G}^{+}$cell immunosuppressive functions. Although both Akt1 and Akt 2 knockdown in $l a l^{-1-}{\text { Ly } 6 \mathrm{G}^{+}}^{+}$ cells rescued the inhibitory effects of $l a l^{-/-} \mathrm{Ly} 6 \mathrm{G}^{+}$cells on co-cultured T-cell proliferation (Figure 6A), only Akt1 knockdown recovered IL-2 lymphokine release by the T cells (Figure 6B).

One mechanism for MDSCs to suppress T-cell function is through the production of ROS. ${ }^{4}$ In our previous studies, ROS production was increased in $\mathrm{CD}_{11} \mathrm{~b}^{+} \mathrm{Ly}_{6 \mathrm{G}} \mathrm{G}^{+}$cells of $\mathrm{lal}^{-1-}$ mice along with impaired mitochondrial function. ${ }^{3,20}$ Injection of rapamycin into $\mathrm{lal}^{-/-}$mice effectively improved mitochondrial function and blocked ROS overproduction in $\mathrm{lal}^{-1-}$ bone marrow $\mathrm{Ly}_{6 \mathrm{G}}{ }^{+}$cells (Figure 7), suggesting that ROS overproduction by $\mathrm{lal}^{-/-} \mathrm{CD} 11 \mathrm{~b}^{+} \mathrm{Ly} 6 \mathrm{G}^{+}$cells is controlled by mTOR signaling. Indeed, antioxidant application against ROS effectively rescued abnormal differentiation of bone marrow $\mathrm{Lin}^{-}$cells to $\mathrm{CD} 11 \mathrm{~b}^{+} \mathrm{Ly}_{6 \mathrm{G}}^{+}$cells (Figure $7 \mathrm{C}$ ). Cross-talk between mTOR signaling and activation of Stat3, Stat 4 , and Stat6 pathways has been observed in $l a l^{-/-}$MDSCs by the mTOR inhibition study (Figure 7D).

In summary, the lysosomal anchored mTOR complexes (including both mTORC1 and mTORC2) play very important roles in mediating LAL-regulated myelopoiesis, MDSC expansion, and MDSC immune suppressive functions. Multiple cellular activities are altered by overactivation of the mTOR pathway in $\mathrm{lal}^{-/-}$mice, including cell metabolic/ energy levels, ROS production, and Stats activation. These pathogenic and cellular activities can be reversed by the mTOR pharmacologic inhibitor rapamycin and PP242, and siRNAs targeting both mTORC1 and mTORC2. Based on this study, we propose that the mTOR pathway may serve as a novel target to modulate the emergence of MDSCs in those pathophysiologic states in which these cells play an immunosuppressive role. In a recent report, mTOR inhibitors alone and in combination with Janus kinase 2 inhibitors effectively inhibit cells of myeloproliferative neoplasms. ${ }^{21}$

\section{Acknowledgments}

We thank Lingyan $\mathrm{Wu}$ for technique assistance and Ting Zhao for mouse genotyping.

\section{Supplemental Data}

Supplemental material for this article can be found at http://dx.doi.org/10.1016/j.ajpath.2013.10.015.

\section{References}

1. Du H, Duanmu M, Witte D, Grabowski GA: Targeted disruption of the mouse lysosomal acid lipase gene: long-term survival with massive 
cholesteryl ester and triglyceride storage. Hum Mol Genet 1998, 7: 1347-1354

2. Qu P, Shelley WC, Yoder MC, Wu L, Du H, Yan C: Critical roles of lysosomal acid lipase in myelopoiesis. Am J Pathol 2010, 176: 2394-2404

3. Qu P, Yan C, Blum JS, Kapur R, Du H: Myeloid-specific expression of human lysosomal acid lipase corrects malformation and malfunction of myeloid-derived suppressor cells in lal-/- mice. J Immunol 2011, 187: 3854-3866

4. Gabrilovich DI, Nagaraj S: Myeloid-derived suppressor cells as regulators of the immune system. Nat Rev Immunol 2009, 9:162-174

5. Ostrand-Rosenberg S, Sinha P: Myeloid-derived suppressor cells: linking inflammation and cancer. J Immunol 2009, 182:4499-4506

6. Condamine T, Gabrilovich DI: Molecular mechanisms regulating myeloid-derived suppressor cell differentiation and function. Trends Immunol 2011, 32:19-25

7. Yan C, Lian X, Li Y, Dai Y, White A, Qin Y, Li H, Hume DA, Du H: Macrophage-specific expression of human lysosomal acid lipase corrects inflammation and pathogenic phenotypes in lal-/- mice. Am J Pathol 2006, 169:916-926

8. Yan C, Ding X, Dasgupta N, Wu L, Du H: Gene profile of myeloidderived suppressive cells from the bone marrow of lysosomal acid lipase knock-out mice. PLoS One 2012, 7:e30701

9. Heitman J, Movva NR, Hall MN: Targets for cell cycle arrest by the immunosuppressant rapamycin in yeast. Science 1991, 253:905-909

10. Sabatini DM, Erdjument-Bromage H, Lui M, Tempst P, Snyder SH: RAFT1: a mammalian protein that binds to FKBP12 in a rapamycindependent fashion and is homologous to yeast TORs. Cell 1994, 78:35-43

11. Brown EJ, Albers MW, Shin TB, Ichikawa K, Keith CT, Lane WS, Schreiber SL: A mammalian protein targeted by G1-arresting rapamycin-receptor complex. Nature 1994, 369:756-758
12. Zoncu R, Efeyan A, Sabatini DM: mTOR: from growth signal integration to cancer, diabetes and ageing. Nat Rev Mol Cell Biol 2011, $12: 21-35$

13. Janes MR, Limon JJ, So L, Chen J, Lim RJ, Chavez MA, Vu C, Lilly MB, Mallya S, Ong ST, Konopleva M, Martin MB, Ren P, Liu Y, Rommel C, Fruman DA: Effective and selective targeting of leukemia cells using a TORC1/2 kinase inhibitor. Nat Med 2010, 16:205-213

14. Thomson AW, Turnquist HR, Raimondi G: Immunoregulatory functions of mTOR inhibition. Nat Rev Immunol 2009, 9:324-337

15. Qu P, Du H, Li Y, Yan C: Myeloid-specific expression of Api6/AIM/Sp alpha induces systemic inflammation and adenocarcinoma in the lung. J Immunol 2009, 182:1648-1659

16. Weissman IL, Shizuru JA: The origins of the identification and isolation of hematopoietic stem cells, and their capability to induce donor-specific transplantation tolerance and treat autoimmune diseases. Blood 2008, 112:3543-3553

17. Qu P, Du H, Wilkes DS, Yan C: Critical roles of lysosomal acid lipase in T cell development and function. Am J Pathol 2009, 174:944-956

18. Gabrilovich DI, Ostrand-Rosenberg S, Bronte V: Coordinated regulation of myeloid cells by tumours. Nat Rev Immunol 2012, 12 $253-268$

19. Laplante M, Sabatini DM: mTOR signaling in growth control and disease. Cell 2012, 149:274-293

20. Yan C, Ding X, Dasgupta N, Wu L, Du H: Gene profile of myeloidderived suppressive cells from the bone marrow of lysosomal acid lipase knock-out mice. PLoS One 2012, 7(2):e30701

21. Bogani C, Bartalucci N, Martinelli S, Tozzi L, Guglielmelli P, Bosi A, Vannucchi AM; Associazione Italiana per la Ricerca sul Cancro AGIMM: mTOR inhibitors alone and in combination with JAK2 inhibitors effectively inhibit cells of myeloproliferative neoplasms. PLoS One 2013, 8:e54826 